\title{
Trombositopenia Berat pada Ibu Hamil dengan Sistemik Lupus Erythematosus yang Dilakukan Seksio Sesarea
}

\author{
Mariza Fitriati, Ratih Kumala, Sri Rahardjo \\ Departemen Anestesiologi \& Terapi Intensif Fakultas Kedokteran Universitas Gadjah Mada-RSUP Dr. Sardjito \\ Yogyakarta
}

\begin{abstract}
Abstrak
Trombositopenia adalah hal yang umum muncul pada kehamilan normal, disebut trombositopenia berat bila jumlah trombosit $<50.000 / \mu \mathrm{L}$. Komplikasi kehamilan oleh penyakit Lupus Eritematosus Sistemik (Systemic Lupus Erythematosus = SLE) dapat menimbulkan trombositopenia berat patologis. Karena peran penting trombosit dalam pembekuan darah, dilain pihak proses persalinan akan menimbulkan perdarahan, maka dibutuhkan jumlah dan fungsi trombosit yang cukup. Trombositopenia-SLE berderajat berat perlu mendapat terapi untuk meningkatkan jumlah dan fungsi trombosit sebelum menjalani persalinan. Upaya peningkatan jumlah trombosit pada trombositopenia-SLE diawali dengan kortikosteroid sebagai terapi awal, dengan terapi alternatif lanjutan imunosupresif, splenektomi, plasmaferesis, trombopoetic, dan konsentrat trombosit. Pada kasus ini trombositopenia tidak dapat teratasi, sehingga pemeriksaan fungsional pembekuan darah bleeding time dan clotting time digunakan untuk membantu memperkirakan kemungkinan terjadi perdarahan berkelanjutan. Perhatian utama pada pemilihan tehnik anestesi kasus ini adalah kemungkinan terjadi perdarahan berkelanjutan, dalam hal ini dipilih yang dipertimbangkan berisiko terkecil yaitu total intravenous anesthesia (TIVA) dengan ketamin. Perawatan pasca operasi dilaksanakan juga dengan tetap mewaspadai kemungkinan terjadi perdarahan berkelanjutan.
\end{abstract}

Kata kunci: trombositopenia berat, kehamilan, lupus eritematosus sistemik, seksio sesarea

\section{Severe Trombositopenia in Pregnant Woman with Sistemic Lupus Erythematosus Ongoing Caesarean Section}

\begin{abstract}
Thrombocytopenia is a common occurrence in normal pregnancy, will classified as severe thrombocytopenia if platelet count $<50.000 / \mu \mathrm{L}$. Pregnancy complicated by Systemic Lupus Erythematosus (SLE) can lead to pathological severe thrombocytopenia. As thrombocytes has a main role in haemostasis, and delivery process will always caused bleeding, thrombocytes needed in proper amount and function. Severe SLE-Thrombocytopenia has to treat aiming higher total thrombocytes and function before delivery. Effort in raising thrombocytes count on SLE-thrombocytopenia patients recommended starting from corticosteroid as first line treatment, followed by any alternatif therapy if thrombocytes count did not responds to corticosteroid therapy, such as immunosuppresif drugs, splenectomy, plasmapharesis, thrombopoetic drugs, and trombocyte concentrate. In this case, severe thrombocytopenia couldn't be resolved, so then the bleeding time and clotting time taken as tools to estimate blood's ability to coagulate. The main consideration on choosing anesthesia's plan in this case is possibility condition to held uncontrolled bleeding. Therefore, the procedure with the lowest risk for maternal and fetal, total intravenous anesthesia with ketamin, had chosen. Caring for post operative SLE-thrombocytopenia patient should never ignoring vigilance for sustainable bleeding.
\end{abstract}

Key words: severe thrombocytopenia, pregnancy, systemic lupus erythematosus, caesarean section 


\section{Pendahuluan}

Lupus Eritematosus Sistemik (Systemic Lupus Erythematosus $=$ SLE) adalah penyakit autoimun kronis yang dapat eksaserbasi akut. Angka kejadian SLE adalah 1,4-21,9 per 100.000 orang, dan prevalensinya $7,4-159,4$ per 100.000 orang, dengan wanita secara disproporsional lebih terpengaruh, dengan prevalensi pada wanita 9:1. ${ }^{1}$ Wanita penderita SLE tetap berpotensi hamil. Kehamilan dan SLE dapat saling mempengaruhi. SLE mempunyai karakteristik terjadinya thrombosis pembuluh darah dan komplikasi selama kehamilan, dengan salah satu manifestasi berupa trombositopenia.

Sejumlah penelitian memberikan laporan peningkatan risiko dua sampai tiga kali lipat terjadi cerawat (flare) selama kehamilan, sementara beberapa penelitian lain tidak menemukan peningkatan risiko. ${ }^{2-4}$ Aktifitas SLE yang dapat diukur muncul pada $40-50 \%$ kehamilan, dengan gejala umum penyakit kulit (25-90\%), Lupus nephfitis (sampai 75\%), artritis $(20 \%)$, dan penyakit hematologik, termasuk trombositopenia (10-40\%). Faktor risiko terjadi flare SLE antara lain adalah penyakit yang aktif dalam 6 bulan sebelum konsepsi, riwayat flare multipel, dan penghentian hidroksiklorokuin. ${ }^{4}$

Flare dapat terjadi pada umur kehamilan berapapun, bahkan sampai pada periode pasca persalinan. ${ }^{5}$ SLE dan kehamilan meningkatkan morbiditas dan mortalitas maternal maupun neonatal. Risiko terjadi preeklampsia berkisar antara 11-35\% (sebagian penelitian menyatakan lebih dekatke $30 \%),{ }^{4,5}$ dibanding $5 \%$ pada populasi umum. Penelitian terhadap 396 kehamilan yang berkomplikasi SLE membandingkan hasil akhir kehamilan sebelum dan setelah muncul SLE. Komplikasi kehamilan setelah muncul SLE adalah peningkatan risiko kematian fetal $(29,7 \%$ vs $14,2 \%)$ dan kelahiran kurang bulan $(26,7 \%$ vs 5,8\%). Prediktor keguguran kehamilan meliputi $\mathrm{LN}$ (odd rasio $=\mathrm{RO} 7,3$ ), antibodi antifosfolipid (RO3,9), danflareSLEselamakehamilan(RO1,9).

Kelahiran kurang bulan berhubungan dengan Lupus Nephritis (RO 19,8), antibodi anti-Ro (RO 13,9), hipertensi (RO 15,7), dan flare
SLE (RO 2,5). ${ }^{6}$ Antibodi anti-Ro berhubungan dengan peningkatan risiko blokade jantung kongenital (1-2\%), lupus neonatal, dan abnormalitas laboratorium, termasuk hematologi (trombositopenia dan neutropenia), dan abnormalitas hepatik (peningkatan transaminase), pada anak asimptomasik dalam 27 hari pertama kehidupannya. ${ }^{7,8}$ Remisi secara klinis aktifitas SLE dan kendali secara hati-hati terhadap penyakit berhubungan dengan perbaikan hasil terapi, dengan menerapkan monitoring secara hati-hati terhadap pasien ini dalam perjalanan kehamilannya. $^{9}$

Trombositopenia adalah temuan hemotologis kedua tersering pada kehamilan setelah anemia. ${ }^{10}$ Hal ini terjadi pada $7-10 \%$ wanita hamil. ${ }^{10}$ Rentang normal jumlah trombosit pada wanita non hamil adalah $150.000-400.000 / \mu \mathrm{L} .{ }^{10,11}$ Trombositopenia didefinisikan sebagai penurunan jumlah trombosit dibawah $150.000 / \mu \mathrm{L}^{10}$ Penurunan jumlah trombosit disebut ringan bila berjumlah $>100.000 / \mu \mathrm{L}$, sedang bila $50.000-100.000 /$ $\mu \mathrm{L}$ dan berat bila $<50.000 / \mu \mathrm{L} .10$ Penyebab penurunan fisiologis adalah multifaktorial dan berhubungan dengan hemodilusi, peningkatan konsumsi dan peningkatan agregasi trombosit yang dipicu oleh peningkatan tromboksan A2, ataupun produksi yang kurang (jarang). ${ }^{10,11}$

Trombosit terlibat dalam hemostasis primer, menutup kerusakan endotelial dan berlaku sebagai permukaan untuk hemostasis sekunder melalui jalur koagulasi. ${ }^{11}$ Bila jumlah trombosit $>50.000 / \mu \mathrm{L}$, biasa tidak terjadi tanda maupun gejala klinis, kecuali bila fungsi trombosit juga terganggu. ${ }^{11}$ Tanda umum trombositopenia meliputi ptechiae, perdarahan hidung (epitaksis) dan lebih jarang lagi hematuria dan perdarahan gastrointestinal. ${ }^{11}$ Efek trombositopenia yang dapat memicu perdarahan berkelanjutan harus diantisipasi sebelum dilakukan tindakan operasi section cesarea. Karena peran penting trombosit dalam pembekuan darah, maka secara nalar, segala prosedur atau tindakan bedah maupun anestesi pada pasien hamil dengan SLE, yang dapat menimbulkan perdarahan, akan membutuhkan jumlah dan fungsi trombosit yang memadai agar terjadi pembekuan darah untuk mencegah 
perdarahan berkelanjutan. Tindakan pembedahan /anestesi yang menyebabkan perdarahan di permukaan, bisa dicapai dan dihentikan dengan koagulasi elektrik dalam tehnik kauterisasi, tetapi tindakan yang dilakukan jauh kedalam dan tidak bisa dicapai dengan tehnik kauterisasi akan sangat mengandalkan kemampuan koagulasi darah untuk penghentian perdarahan bila terjadi perlukaan pembuluh darah/perdarahan. Karena itu, gangguan koagulasi darah merupakan salah satu kontraindikasi relatif dalam tindakan blokade subarachnoid dan peridural. ${ }^{12,13}$ Bila terjadi trombositopenia pada penderita SLE, terapi lini pertama adalah kortikosteroid, yang banyak memberikan hasil yang baik $^{14}$ pada trombositopenia akut. Sebagai kontras adalah trombositopenia kronis yang kurang responsif terhadap terapi ini; membutuhkan dosis kortikosteroid yang lebih tinggi, dan lebih sulit diterapi secara efektif.

Pada keadaan kegagalan terapi kortikosteroid standar, salah satu obat imunosupresif yang biasa digunakan adalah: azathiopirine (AZA), mycophenolate mofetil (MMF), cyclosporine (CsA), atau methotrexate (MTX). ${ }^{15}$ Pada kasus tertentu, terapi danazol juga diterapkan. Jika obat imunosupresif tidak efektif, dapat dipertimbangkan splenektomi, walaupun opini tentang prosedur ini masih bervariasi dan sangat bergantung pada kondisi klinis pasien dan pendapat ahli. Problem utama adalah kemungkinan melakukan terapi bedah/anestesi dengan kadar trombosit yang rendah, efektifitas tindakan, dan peningkatan risiko infeksi setelah prosedur. ${ }^{16,17}$ Pada trombositopenia berat yang resisten terhadap terapi standar kortikosteroid, cyclophospamide (CTX) digunakan intravena dalam terapi imunoglobulin dan pulse therapy. ${ }^{18,19}$ Bersamaan dengan terapi tersebut, ataupun bila CTX gagal, dapat digunakan plasmaferesis sebagai metode untuk mengeluarkan antibodi tersirkulasi yang menghancurkan trombosit. Bila metode ini juga belum efektif, terapi dengan rituximab (antibodi monoklonal anti-CD20, RTX) $)^{20,21}$ dapat dipertimbangkan, demikian juga transplantasi autolog atau allogenic sel induk sumsum tulang. ${ }^{22,23}$ Metode terapi trombositopenia terbaru meliputi penggunaan obat yang menstimulasi thrombopoesis, yaitu agonis reseptor thrombopoesis (romiplostim, eltrompobag) ataupun faktor pertumbuhan thrombopoetic (IL-11). ${ }^{24}$ Tetapi saat ini belum ada data yang tersedia tentang penggunaan obat ini pada pasien SLE dengan trombositopenia. Karena sifat alami imunologi abnormalitas hematologis pada SLE, penggunaan konsentrat trombosit tidak selalu direkomendasikan. Pengecualian adalah pada perdarahan aktif atau pembedahan terencana, ketika trombosit dibawah $30.000 / \mu \mathrm{L} .{ }^{25}$

Karena mayoritas obat imunosupresif untuk terapi lupus juga dapat menyebabkan maupun memperparah trombositopenia, ${ }^{25}$ dan mungkin mempunyai efek pada fetus, ${ }^{25}$ keputusan penggunaan terapi imunosupresif dapat menjadi sangat sulit. Dibutuhkan pengalaman medis untuk hal ini dan terapi individual untuk setiap pasien. Pada laporan ini, kami akan menjabarkan sebuah laporan kasus seorang wanita hamil dengan komorbid SLE yang harus menjalani operasi seksio sesarea dengan manifestasi trombositopenia berat yang refrakter terhadap pemberian terapi untuk menaikkan jumlah trombosit dalam upaya meminimalkan resiko perdarahan.

\section{Kasus}

\section{Anamnesa}

Seorang wanita, 30 th dengan berat badan 55 $\mathrm{kg}$ dan tinggi badan $156 \mathrm{~cm}$ (BMI 22), dengan diagnosa $\mathrm{G}_{2} \mathrm{P}_{1} \mathrm{~A}_{\mathrm{o}}$ 37-38 minggu, tunggal, hidup, letak sungsang, bekas seksio sesarea dengan sistemik lupus erythematosus (SLE) direncanakan seksio sesarea terencana. Pasien sudah diketahui mempunyai penyakit penyerta SLE sejak sebelum menikah dan secara rutin berobat ke dokter spesialis penyakit dalam subspesialis rhematologi. Persalinan pertama dilakukan dengan seksio sesarea menggunakan pembiusan regional anestesi subarachnoid blok dengan angka trombosit $30.000 / \mu \mathrm{L}$ setelah diberikan methylprednisolon, imonoglobulin, dan trombosit konsentrat. Pasien kontrol rutin dan mendapatkan terapi Promavit 1x1, Prolacta 1x1, Cal-95 1x1, hemobion 1x1, sandimun 1x1, methylprednisolon $8 \mathrm{mg} 1 \times 1$, cloraquin $1 \times 1$. Tidak 
Pemeriksaan Fisik

\begin{tabular}{|c|c|}
\hline \multicolumn{2}{|l|}{ Keadaan umum } \\
\hline Kesadaran & sadar baik \\
\hline GCS & 456 \\
\hline Tekanan darah & $100 / 60 \mathrm{mmHg}$ \\
\hline laju nadi & $88 \mathrm{x} /$ menit \\
\hline laju nafas & 20x/menit \\
\hline suhu & $36,6^{\circ} \mathrm{C}$ \\
\hline $\mathrm{SpO}_{2}$ & $100 \%$ dengan udara bebas \\
\hline Kepala & anemia -/-, sklera ikterus -/- \\
\hline Mulut & buka mulut 3 jari, Mallampati 3 \\
\hline Leher & pendek, jarak tryromental 3 jari \\
\hline Thoraks & bentuk dan gerak simetris \\
\hline Cor & $\begin{array}{l}\text { S1S2 tunggal, reguler, gallop (-), } \\
\text { murmur (-) }\end{array}$ \\
\hline Pulmo & $\begin{array}{l}\text { uara nafas normal vesikuler, } \\
\text { ronkhi -/-, wheezing -/- }\end{array}$ \\
\hline Abdomen & $\begin{array}{l}\text { hamil sesuai umur kehamilam } 9 \\
\text { bulan }\end{array}$ \\
\hline Extremitas & $\begin{array}{l}\text { akral hangat, CTR }<2 \text { detik, } \\
\text { edema tungkai }+/+\end{array}$ \\
\hline Laju jantung & fetus $140-150 \mathrm{x} /$ menit \\
\hline
\end{tabular}

Pemeriksaan Penunjang

Tabel 1. Pemeriksaan darah

\begin{tabular}{ll}
\hline 26 Oktober 2019 & Hb $10,2 \mathrm{~g} / \mathrm{dL}$ \\
& Leuko $1.890 / \mu \mathrm{L}$ \\
& Trombo $11.000 / \mu \mathrm{L}$ \\
& SGOT/PT: $11,9 / 10,6$ \\
& Hb $9,8 \mathrm{~g} / \mathrm{dL}, \mathrm{Hct}:$ \\
& $30,7 \%$ \\
& Leuko $1.920 / \mu \mathrm{L}$ \\
& Trombo $19.000 / \mu \mathrm{L}$ \\
& Alb 3,29 g/dL SGOT/ \\
& PT $: 10 / 6$ \\
& BUN/SC: $6,6 / 0,47$ \\
& Na/K/Cl: $136 / 3.30 /$ \\
& $107 \mathrm{mEq} / \mathrm{L}$ \\
& BT/CT: $1 / 12 \quad$ PPT: \\
& 13.5 APTT 32,3 INR \\
& 1,07 \\
& LED $114 \quad$ CRP 17,4 \\
& HbsAg (-) anti HIV (-) \\
\hline
\end{tabular}

didapatkan riwayat alergi makanan maupun obat obatan.
Pengelolaan Anestesi

Jumlah trombosit yang sangat rendah menjadi pertimbangan tehnik anestesi yang dipilih. Rendahnya jumlah tersebut sudah menimbulkan manifestasi berupa ptechiae, purpura, gusi berdarah saat menyikat gigi meskipun belum menimbulkan mimisan (epitaksis). Hal ini pula yang menjadikan kekhawatiran dari operator untuk melakukan operasi yang beresiko terjadinya perdarahan. Riwayat persalinan sebelumnya dipelajari kembali. Pada bulan Nopember tahun 2014 pasien masuk rumah sakit dengan jumlah trombosit $17.000 / \mu \mathrm{L}$ dengan adanya ptechie dan purpura di lengan. Direncanakan untuk operasi seksio sesarea elektif disebabkan posisi janin sungsang dan non stress test (NST) suspisius. Setelah berkonsultasi dengan konsultan hematologi dan konsultan rhematoid diputuskan untuk memperbaiki jumlah trombosit selama tidak ada kondisi emergensi pada ibu maupun janinnya. Selama 1 minggu diupayakan menaikkan jumlah trombosit dengan target sampai diatas $50.000 / \mu \mathrm{L}$ dengan menggunakan methylprednisolon, imunoglobulin, dan juga transfusi trombosit konsentrat, tetapi hasil yang didapatkan tidak terlalu signifikan seperti yang diharapkan bahkan beberapa kali jumlah trombosit turun setelah diberikan terapi tersebut. Akhirnya diputuskan untuk dilakukan seksio sesarea saat trombosit $30.000 \mu / \mathrm{L}$, dengan persiapan darah 2 kantong whole blood group screen hold (GSH). Operasi berlangsung selama 40 menit dengan perkiraan jumlah perdarahan $300 \mathrm{cc}$. Pasien pulang setelah 4 hari paska operasi.

Berdasarkan riwayat persalinan sebelumnya tersebut diupayakan untuk menaikkan jumlah trombositdenganmemberikanmethylprednisolon, imunoglobulin dan transfusi trombosit konsentrat. Tetapi peningkatan jumlah angka trombosit tidak signifikan. Namun pemeriksaan laboratorium menunjukkan Bleeding time dan clotting time normal. Akhirnya dilakukan operasi saat jumlah trombosit $22.000 \mu / L$ dengan persiapan darah sama dengan saat operasi pertama 5 tahun yang lalu. Yang berbeda dengan operasi yang sebelumnya adalah pemilihan tehnik anestesinya dimana dipilih dengan pembiusan total menggunakan obat ketamin dengan tehnik TIVA tanpa intubasi. 


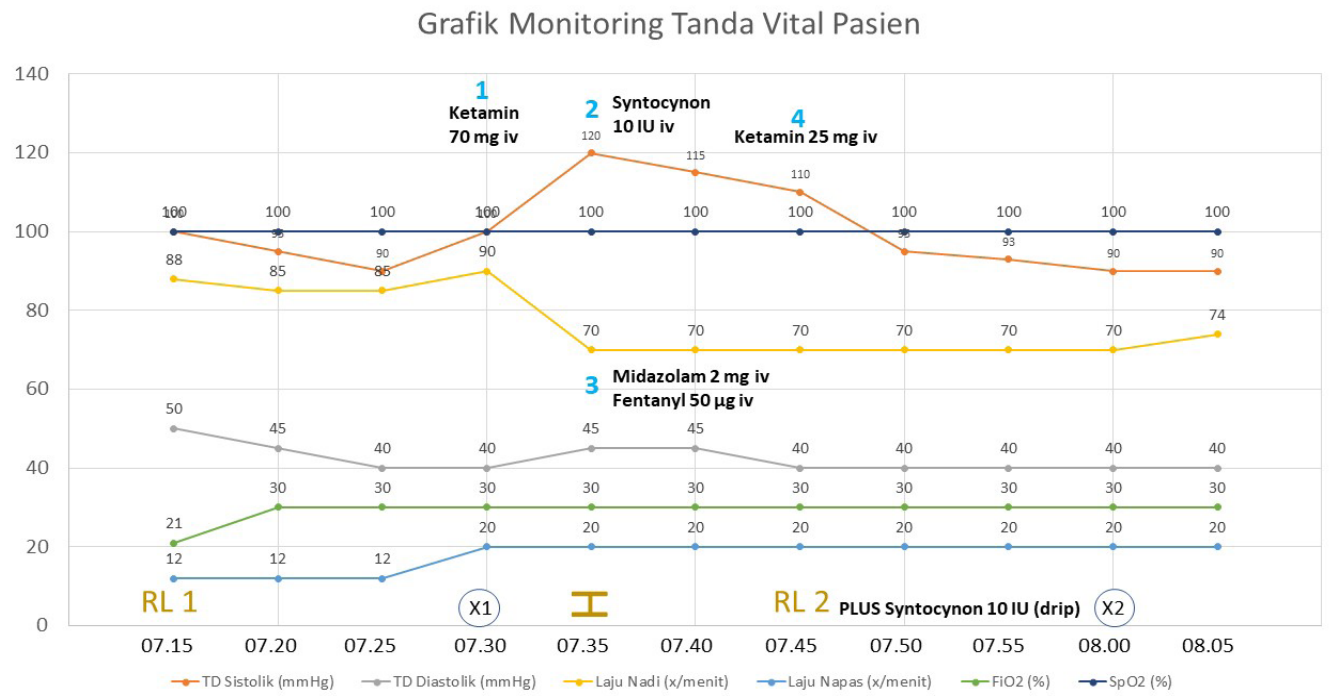

Grafik 1. Monitoring Tanda Vital Pasien. Grafik ini menunjukkan tanda vital pasien terhadap waktu, waktu pembiusan dan operasi dimulai maupun diakhiri, pemberian oksigen, pemberian cairan durante operasi, pemberian obat durante operasi, dan waktu bayi lahir.

Pasien dan keluarga dijelaskan tentang rencana operasi dan pembiusan termasuk masalah dan resiko yang bisa terjadi aktual maupun potensial. Setelah persetujuan didapatkan, pasien disiapkan untuk operasi. Pasien dipuasakan 6 jam makanan padat dan 2 jam air putih/teh, dipasang infus ringer laktat $50 \mathrm{cc} / \mathrm{jam}$, dan diberikan antasida 30 cc 30 menit sebelum dibawa ke kamar operasi. Peralatan, mesin, obat anestesi dan emergensi baik untuk ibu maupun untuk janin sudah disiapkan. Setelah dilakukan evaluasi prainduksi dengan tekanan darah 100/50 $\mathrm{mmHg}$, nadi 88 $\mathrm{x} /$ menit, frekuensi nafas $18 \mathrm{x} /$ menit dan $\mathrm{SpO}_{2}$ $100 \%$, daerah operasi mulai dipersiapan dengan didesinfeksi dan ditutup dengan kain steril (drapping).

Pasien diberikan oksigen nasal canula $2 \mathrm{lpm}$. Prosedur time out dilakukan. Ketamin $70 \mathrm{mg}$ disuntikan secara intravena. Setelah didapatkan efek nistagmus, operator diminta untuk mengevaluasi efek anakgesik dengan menjepit kulit daerah operasi dengan pinset, dan kemudian melakukan insisi setelah dievaluasi efek analgesik ketamin telah bereaksi dengan baik. Bayi laki laki lahir bugar 5 menit setelah insisi dengan ketuban jernih. Setelah tali pusat dipotong, diberikan midazolam $2 \mathrm{mg}$ dan fentanyl $50 \mu \mathrm{g}$ intravenous
Selanjutnya ketamin $25 \mathrm{mg}$ intravenous diberikan setiap 15 menit. Operasi berlangsung selama 30 menit dengan jumlah perdarahan $200 \mathrm{cc}$. Obat untuk analgesik, antiemetik paska operasi dan obat kontraksi rahim diberikan sesuai standart. Tekanan darah selama operasi berkisar 9-120/45$50 \mathrm{mmHg}$, nadi $70-90 \mathrm{x} /$ menit. Berat badan bayi 2750 gr dengan Apgar Score 8-9.

\section{Pengelolaan Pascabedah}

Paska operasi pasien diobservasi ketat di ICU disebabkan adanya kemungkinan perdarahan paska operasi. Parameter hemodinamik dimonitor ketat, perdarahan dari luka operasi maupun pervaginam dievaluasi berkala, dan dilakukan pemeriksaan laboratorium. Pasien segera dimobilisasi dan diberikan intake oral. Keesokkan harinya pasien dipindah ke ruangan, dengan tidak ada masalah perdarahan dan juga tidak ada keluhan dari pasien. Pasien pulang 2 hari setelah operasi.

\section{Pembahasan}

Kasus pasien ini merupakan kasus perulangan kehamilan dengan SLE-trombositopenia, setelah lima tahun sebelumnya pasien mengalami hal yang sama. Pada kehamilan terdahulu, kombinasi terapi metilprednisolon, imunoglobulin, dan tranfusi 
trombosit dapat menaikkan jumlah trombosit dari $17.000 / \mu \mathrm{L}$ menjadi $30.000 / \mu \mathrm{L}$ dengan waktu terapi 1 minggu, dan pasien diputuskan menjalani operasi dengan indikasi posisi janin sungsang, NST suspicious, dan karena terapi kombinasi yang tidak terlalu signifikan dalam menaikkan jumlah trombosit (bahkan terdapat momen sesaat penurunan trombosit setelah terapi). Untuk persiapan operasi saat itu, disediakan 2 kantong darah whole blood. Operasi dikerjakan pada saat jumlah trombosit $30.000 / \mu \mathrm{L}$, perdarahan operasi total $300 \mathrm{ml}$, tanpa perdarahan berkelanjutan, dan pasien pulang 4 hari pasca persalinan. Tehnik anestesi yang dipilih saat itu adalah anestesi neuraksial subarachnoid block.

Berdasarkan riwayat persalinan tersebut, untuk menjalani prosedur persalinan diperlukan peningkatan jumlah trombosit berdasar risiko perdarahan maternal pada persalinan, tindakan anestesi, ataupun sesarea ${ }^{25}$ maka pada kehamilan kasus kali ini diberikan terapi kombinasi serupa, yaitu pemberian metilprednisolon, imunoglobulin, dan tranfusi konsentrat trombosit. Pasien SLE ini mendapat metilprednisolon secara rutin. Hal ini mungkin menjadi penyebab terapi metilprednisolon yang diberikan dengan dosis yang lebih tinggi pun, tidak memberikan efek yang diharapkan, karena telah terjadi resistensi terhadap steroid. ${ }^{26}$ Karena terapi kortikosteroid gagal, dipertimbangkan obat imunosupresif methotrexat. Tetapi methotrexat berpotensi memperburuk kondisi trombositopenia akibat efek imunosupresif-nya, ${ }^{27}$ maka methotrexat tidak diberikan. Alternatif splenektomi tidak dikerjakan karena pertimbangan umur kehamilan yang telah cukup bulan sehingga secara tehnis sulit dan berisiko tinggi bila dikerjakan. Plasmafaresis dan obat trombopoetik belum tersedia ditempat. Konsentrat trombosit tetap diberikan, sekalipun untuk sifat alami abnormalitas imunologi SLE konsentrat trombosit bukan merupakan terapi terpilih, karena pasien direncanakan menjalani pembedahan elektif. ${ }^{25}$ Evaluasi laboratorium menunjukkan bleeding time dan clotting time normal, dengan jumlah trombosit $22.000 / \mu \mathrm{L}$. Dengan dasar bahwa pemeriksaan BT dan CT normal, dan bahwa upaya meningkatkan jumlah trombosit tidak menunjukkan hasil signifikan (yang bahkan hasil terakhir lebih rendah dibanding hasil terapi pada persalinan sebelumnya), maka diputuskan segera dilakukan operasi.

Tehnik anestesi terpilih adalah total intravenous anesthesia (TIVA) menggunakan ketamin tanpa intubasi. Pilihan ini diambil dengan pertimbangan memperkecil risiko terjadi perdarahan yang tak disengaja bila dilakukan tehnik anestesi neuraksial, yang penanganan perdarahan ini akan sangat sulit dilakukan karena sumber perdarahan tidak dapat dicapai dengan kauterisasi. Perdarahan tersebut dapat menyebabkan efek penekanan ruangan terhadap pembuluh darah dan persarafan. Dengan menggunakan ketamin, refleks batuk pasien relatif tetap terjaga, dan hipersalivasi yang terjadi sebagai efek samping dapat diatasi dengan obat pengering. Intubasi tidak dikerjakan untuk menghindari kemungkinan terjadi perdarahan jalan napas, yang karena mengingat jumlah trombosit yang minimal terdapat kemungkinan sulit dihentikan. Refleks batuk yang terjaga pada pemberian ketamin dapat membantu mencegah kejadian aspirasi. Tanda vital pasien yang normal dan stabil juga merupakan pertimbangan menggunakan tehnik TIVA dengan ketamin. ${ }^{28}$

Informed consent dan prosedur standar praanestesi untuk ibu hamil dilakukan sebelum dikerjakan anestesi dan operasi. Dua kantong whole blood disiapkan sebagai persiapan menghadapi kemungkinan terjadi perdarahan besar. Anestesi dikerjakan dengan piranti monitoring standar dan penambahan oksigen diberikan dengan nasal kanula 2 lpm. Ketamin diberikan intravena, dan insisi dikerjakan setelah efek anestesi ketamin muncul. Lima menit setelah insisi, bayi lahir bugar dengan ketuban jernih. Pada kasus ini ketamin terlihat tidak mempengaruhi kebugaran bayi.

Setelah tali pusat dipotong diberikan ajuvan midazolam $2 \mathrm{mg}$ dan fentanyl $50 \mu \mathrm{g}$ intravena, pemeliharaan anestesi dikerjakan dengan injeksi $25 \mathrm{mg}$ ketamin intravena tiap 15 menit. Pemberian midazolam dan fentanyl sebagai ajuvan dilakukan setelah tali pusat dipotong agar tidak terjadi transmisi obat ke bayi, dengan efek yang diharapkan adalah dapat mengurangi total dosis ketamin yang diberikan dibandingkan 
dengan bila ketamin tunggal sebagai obat anestesi. Fentanyl memperkuat efek analgesia ketamin secara multimodal. ${ }^{29}$ Midazolam menambah efek sedasi sekaligus juga dapat mengurangi efek nightmare akibat pemberian ketamin..$^{30}$

Operasi berlangsung 30 menit, perdarahan total $200 \mathrm{ml}$, dan tanda vital stabil selama operasi. Jumlah perdarahan yang minimal dan tanda vital yang stabil menunjukkan kemungkinan fungsi pembekuan darah pasien dapat bekerja dengan baik. Obat analgesik, antiemetik, dan uterotonik diberikan sesuai standar. Pemberian uterotonik memperkuat upaya penghentian perdarahan dan pencegahan kejadian perdarahan berkelanjutan.

Kelancaran proses operasi dan kestabilan tanda vital selama operasi tidak boleh menjadi penyebab pengurangan kewaspadaan, sehingga pasca operasi pasien diobservasi di ICU. Observasi dilakukan terhadap kemungkinan perdarahan berkelanjutan, dengan monitor parameter hemodinamik, perdarahan per-luka operasi dan pervaginam, serta pemeriksaan laboratorium.

Mobilisasi dini segera dilakukan dan intake oral diberikan. Dengan mobilisasi dini dan intake oral, diharapkan pemulihan dapat terjadi lebih cepat. Kondisi pasien selama di ICU stabil, tidak ada perdarahan, maupun keluhan, sehingga satu hari kemudian dapat dipindahkan ke ruang perawatan biasa dan keluar rumah sakit pada hari kedua pasca operasi.

\section{Simpulan}

Pada ibu hamil dengan SLE, perbaikan trombositopenia perlu dilakukan semaksimal mungkin untuk memperkecil risiko perdarahan berkelanjutan, dengan tetap memperhatikan evaluasi kecenderungan hasil terapi. Adanya kecenderungan kenaikan jumlah trombosit yang tidak signifikan, atau bahkan ada momen penurunan jumlah trombosit dapat menjadi pertimbangan untuk segera melakukan tindakan operatif, disamping kondisi klinis ibu dan janin. Modalitas perbaikan kondisi tetap diutamakan bilamana tidak ada kegawatan ibu dan/atau janin. Pemilihan tehnik anestesi pada pasien hamil dengan trombositopenia-SLE perlu memperhatikan kondisi ibu dan janin, risiko perdarahan berkelanjutan sebelum, selama, dan setelah operasi, dan ketersediaan kemampuan suportif maupun terapeutik bila terjadi perdarahan berkelanjutan. Pilihan yang diambil sebaiknya adalah yang dengan risiko terkecil untuk ibu dan janin. Perdarahan minimal dan kestabilan tanda vital selama operasi pada pasien hamil dengan trombositopenia-SLE tidak boleh menurunkan kewaspadaan akan kemungkinan terjadi perdarahan berkelanjutan pada masa pasca operasi.

Penanganan ibu hamil dengan trombositopeniaSLE memerlukan kerjasama tim yang solid dengan prinsip mengutamakan keluaran pasien. Tim solid ini perlu mempunyai hubungan yang baik dengan keluarga, sehingga komunikasi informasi dan edukasi dapat dilakukan dengan baik sampai ke prognosis pasien, dan diharapkan dapat memberikan hasil berupa dukungan/ kerjasama yang baik dari keluarga. Tim ini sebaiknya juga merupakan tim yang tetap sama komposisinya, baik pada kehamilan pertama maupun ke kehamilan berikutnya, agar dapat terjadi pemahaman yang baik terhadap pasien.

\section{Daftar Pustaka}

1. Ortega LM, Schultz DR, Lenz O, Pardo V, Contreras GN. Review: Lupus nephritis: pathologic features, epidemiology and a guide to therapeutic decisions. Lupus 2010;19:557-74.

2. Zen M, Ghirardello A,IaccarinoL,Tonon M, Campana C, Arienti S, Rampudda M, Canova M, Doria A. Hormones, immune response, and pregnancy in healthy women and SLE patients. Swiss Med Wkly 2010;140:187-201.

3. Petri M. Sex hormones and systemic lupus erythematosus. Lupus 2008; 17:412-15.

4. Clowse ME. Lupus activity in pregnancy. Rheum Dis Clin North Am 2007; 33:237-52.

5. PetriM. Hopkins Lupus Pregnancy Center 1987 to 1996. Rheum Dis Clin North Am 1997; 23: 1-13. 
6. Al Arfaj AS, Khalil N. Pregnancy outcome in 396 pregnancies in patients with SLE in Saudi Arabia. Lupus 2010; 19: 1665-73.

7. Brucato A, Cimaz R, Caporali R, Ramoni V, Buyon J. Pregnancy outcomes in patients with autoimmune diseases and anti-Ro/SSA antibodies. Clin Rev Allergy Immunol 2011; 40: $27-41$.

8. Izmirly PM, Saxena A, Kim MY, Wang D, Sahl SK, Llanos C, Friedman D, . Maternal and fetal factors associated with mortality and morbidity in a multi-racial/ethnic registry of antiSSA/Ro-associated cardiac neonatal lupus. Circulation 2011; 124(11): 1927-35.

9. Georgiou PE, Politi EN, Katsimbri P, Sakka V, Drosos AA. Outcome of lupus pregnancy: A controlled study. Rheumatology (Oxford) 2000; 39: 1014-19.

10. Usha P, Lori R. Maternal thrombocytopenia in pregnancy. Proceedings in Obstetrics and Gynecology, 2013; 3 (1):6.

11. CiobanuAM, ColibabaS, CimpocaB,Peltecua G, Panaitescu AM, Thrombocytopenia in Pregnancy. Maedika 2016; 11 (1): 55-60.

12. Redjeki IS, Zulfariansyah A., Rachman IA, Prihartono MA, Budipratama D. Prosedur Anestesi Regional dengan Sub Arachnoid Block. Pedoman Praktek Klinis Anestesiologi. 2013; 7-8.

13. Keputusan Menteri Kesehatan Republik Indonesia Nomor : HK.02.02 / Menkes / 251 / 2015 Bab IV Panduan Anestesi Regional Pedoman Nasional Pelayanan Kedokteran Anestesiologi dan Terapi Intensif, Pengurus Pusat Perhimpunan Dokter Spesialis Anestesiologi dan Terapi Intensif Indonesia, 2015; 33-56.

14. Mok CC, Lee KW, Ho CT, Lau CS, Wong RW. A prospective study of survival and prognostic indicators of systemic lupus erythematosus in a southern Chinese population. Rheumatology 2000; 39: 399406.

15. Leszczyński P, Pawlak-Bus K. New treatment strategy including biological agents in patients with systemic lupus erythematosus. Pol Arch Med Wewn. 2013; 123(9): 482-90.

16. Jacobs P, Wood L, Dent DM. Splenectomy and the thrombocytopenia of systemic lupus erythematosus. Ann Intern Med. 1986; 105: 971-72.

17. Gruenberg JC, VanSlyck EJ, Abraham JP. Splenectomy in systemic lupus erythematosus. Am J Surg. 1988; 155: 39194.

18. Hall S, McCormick JL Jr, Greipp PR, Michet CJ Jr, McKenna CH. Splenectomy does not cure the thrombocytopenia of systemic lupus erythematosus. Ann Intern Med. 1985; 102: $325-28$.

19. Boumpas DT, Barez S, Klippel JH, Balow JE. Intermittent cyclophosphamide for the treatment of autoimmune thrombocytopenia in systemic lupus erythematosus. Ann Intern Med. 1990; 112: 674-7.

20. Maier WP, Gordon DS, Howard RF, Saleh $\mathrm{MN}$, Miller SB, Lieberman JD, et al. Intravenous immunoglobulin therapy in systemic lupus erythematosus - associated thrombocytopenia. Arthritis Rheum. 1990; 33: $1233-39$.

21. Lehembre S, Macario-Barrel A, Musette P, Carvalho P, Joly P. Rituximab treatment for immune thrombocytopenia associated with systemic lupus erythematosus. Ann Dermatol Venereol. 2006; 133: 53-5.

22. Ramos-Casals M, Brito-Zeron $\mathrm{P}$, Munoz S, Soto MJ, BIOGEAS STUDY Group. A systematic review of the off-label use of biological therapies in systemic autoimmune diseases. Medicine. 2008; 87: 345-64. 
23. Traynor AE, Barr WG, Rosa RM, Rodriguez J, Oyama Y, Baker S, et al. Hematopoietic stem cell transplantation for severe and refractory lupus. Analysis after five years and fifteen patients. Arthritis Rheum. 2002; 46: 2917-23.

24. Lisukova IA, Sizikova SA, Kulagin AD, Kruchkova IV, Gilevich AV, Konenkova LP, et al. High-dose immunosuppression with autologous stem cell transplantation in severe refractory systemic lupus erythematosus. Lupus 2004; 13: 89-94.

25. The American College of Obstricians and Gynecologists. Thrombosytopenia in pregnancy.Clinical management guidelines for obstetericians-gynecologists. Practice Bulletin 2016; 128(3): e43-53.

26. Hashimoto H. Glucocorticoid Therapy in Systemic Lupus Erythematosus - Clinical Analysis of 1,125 Patients with SLE. DOI: $10.5772 / 52044$.
27. Jih DM, Werth VP. Thrombocytopenia after a single test dose of methotrexate. Journal of the American Academy of Dermatology 1998; 39 (2): 349-51.

28. Mion G, Villevieille T. Ketamine Pharmacology: an update (pharmacodynamics andmolecular aspects, recent findings). CNS Neuroscience \& Therapeutics 2013; 19: 37080.

29. Tucker AP, Kim YI, Nadeson R, Goodchild $\mathrm{CS}$. Investigation of the potentiation of the analgesic effects of fentanyl by ketamine in humans: a double-blinded, randomised, placebo controlled, crossover study of experimental pain[ISRCTN83088383]. BMC Anesthesiology 2005; 5:2 doi:10.1186/14712253-5-2.

30. Deng XM, Xiao WJ, Luo, MP, Tang GJ, Xu KL. The use of midazolam and small-dose ketamine for sedation and analgesia during local anesthesia. Anesth \& Analg. 2001; 93 (5): 1174-7. 